\title{
Validity Evidence of a Scale on Academic Expectations for Higher Education
}

\author{
Denise de Souza Fleith ${ }^{1}$ \\ Leandro Silva Almeida ${ }^{2}$ \\ Claisy Maria Marinho-Araujo ${ }^{1}$ \\ Cristiano Mauro Assis Gomes ${ }^{3}$ (C) \\ Cynthia Bisinoto ${ }^{1}$ \\ Mauro Luiz Rabelo ${ }^{1}$
}

\begin{abstract}
By using structural equation modeling, this study investigated the dimensionality and invariance of the Brazilian scale of Academic Expectations for Higher Education - short version. The sample consisted of 6,913 students from a Brazilian public university. The results showed good adjustment of the proposed solution containing seven factors: Quality of Academic Education, Social and Academic Commitment, Expansion of Interpersonal Relationships, Opportunity for Student Exchange and Internationalization, Perspective of Professional Success, Concern with Self-Image, and Development of Transversal Skills. The results indicate that the scale is invariant with regard to different groups: students who entered university traditionally and those who entered through social programs for minorities, male and female students, and part-time, full-time or non-working students. The scale can support higher education institutions in the development of educational policies, programs and academic services.
\end{abstract}

Keywords: expectations, higher education, students, scaling

\section{Evidências de Validade de uma Escala sobre Expectativas Acadêmicas para Educação Superior}

\begin{abstract}
Resumo: Usando a modelagem por equações estruturais, este estudo investigou a dimensionalidade e invariância da Escala Brasileira de Expectativas Acadêmicas para Ingressantes na Educação Superior - versão abreviada. A amostra consistiu de 6.913 estudantes de uma universidade pública brasileira. Os resultados apontaram um bom ajustamento da solução proposta de sete fatores: Qualidade da Formação Acadêmica, Compromisso Social e Acadêmico, Ampliação das Relações Interpessoais, Oportunidade de Internacionalização e Intercâmbio, Perspectiva de Sucesso Profissional, Preocupação com Autoimagem e Desenvolvimento de Competências Transversais. Os resultados sugeriram que a escala é invariante considerando diferentes grupos: estudantes que ingressaram na universidade pelo sistema universal e os que ingressaram por meio de programas sociais para minorias, estudantes do sexo masculino e do feminino, e estudantes trabalhadores em tempo parcial e total ou não trabalhadores. A escala pode subsidiar instituições de educação superior no desenvolvimento de políticas educacionais, programas e serviços acadêmicos.
\end{abstract}

Palavras-chave: expectativas, educação superior, estudantes, escalas

\section{Evidencias de la Validez de una Escala sobre las Expectativas Académicas para la Educación Superior}

Resumen: A partir del empleo de modelos de ecuaciones estructurales, este estudio investigó la dimensionalidad y la invariancia de la Escala Brasileña de Expectativas Académicas para Ingresantes en Educación Superior, versión abreviada. La muestra consistió en 6.913 estudiantes de una universidad pública brasileña. Los resultados apuntaron una buena adaptación de la solución propuesta con siete factores: Calidad de la Formación Académica, Compromiso Social y Académico, Expansión de las Relaciones Interpersonales, Oportunidad de Internacionalización e Intercambio, Perspectiva de Éxito Profesional, Preocupación por la Autoimagen y Desarrollo de Competencias Transversales. Esto indica que la escala es invariante considerando diferentes grupos: estudiantes que ingresaron a la universidad mediante el sistema universal y aquellos que ingresaron por medio de programas sociales para minorías, estudiantes del sexo masculino y femenino, y estudiantes que trabajan a tiempo parcial y a tiempo completo o que no trabajan. La escala puede servir de soporte a las instituciones de educación superior en el desarrollo de políticas educativas, programas y servicios académicos.

Palabras clave: expectativas, educación superior, estudiantes, escalas

${ }^{1}$ Universidade de Brasília, Brasília-DF, Brazil
${ }^{2}$ Universidade do Minho, Braga, Portugal
${ }^{3}$ Universidade Federal de Minas Gerais, Belo Horizonte-MG, Brazil

Correspondence address: Denise de Souza Fleith. Universidade de Brasília. Instituto de Psicologia, Campus Darcy Ribeiro, Brasília-DF, Brazil. CEP 70.910-900. E-mail: fleith@unb.br
The emphasis on the strategic importance of higher education for the social and economic development of people and nations has been increasingly acknowledged worldwide (Organization for Economic Co-operation and Development [OECD], 2014, 2017; United Nations Educational, Scientific and Cultural Organization [UNESCO], 2017). According to 
UNESCO (2017), the number of students enrolled in higher education worldwide rose from 99.7 million in the year 2000 to 212.7 million in 2015. In Brazil, the expansion of higher education, accompanied by the more democratic access, led not only to a considerable increase in the number of students in most states, but also to the progressive differentiation of the university population. This expansion has taken place through the access of students from poorer sociocultural groups or minority ethnic groups, as well as older students, to higher education (Rabelo, Bisinoto, Marinho-Araujo, Griboski, \& Meneghel, 2015; Ristoff, 2014). The most recent Brazilian Census of Higher Education (Instituto Nacional de Estudos e Pesquisas Educacionais Anísio Teixeira [INEP], 2017) showed that 2,364 Higher Education Institutions (HEI) - 295 public and 2,069 private - have all 8,027,297 enrollments in undergraduate courses. Of this group, according to the census, almost $50 \%$ corresponded to students aged 25 years or older ( $20 \%$ between 25 and 29 years old and $28.8 \%$ aged 30 years or older), as opposed to $50.8 \%$ of young people in the age range between 18 and 24 years and $0.4 \%$ of students who entered higher education under the age of 18 years.. The majority (56\%) consisted of female students. Among the graduates in 2013, 28.5\% were young people whose parents did not finish primary education. According to INEP (2017) and Rabelo et al. (2015) by attending university, these students became the first university generation in their family.

The current profile of a significant part of Brazilian university students is considered different from the "traditional student", who is in the expected age range for this education level, has a good family background, sufficient financial resources to maintain himself, motivation to make professional choices and, usually, an educational trajectory of social inclusion and academic success. The so-called "new student" in Brazilian higher education chooses and takes evening courses at private higher education institutions (HEI), with low selectivity and short-term; uses part of his time for his own and/or his family's subsistence; tends to belong to the first generation with access to higher education; has no time, space and appropriate conditions to study; and has many difficulties to conciliate family and/or professional responsibilities with academic activities, particularly extraclass activities, such as research projects, participation in scientific events or in community service activities (Britto, Silva, Castilho, \& Abreu, 2008; Ristoff, 2014). Consequently, it is anticipated that students may differ in their academic expectations, competences and motivations, study habits, and professional projects, or in their autonomy and maturity levels to cope with the challenges and demands of higher education (Marinho-Araújo, Fleith, Almeida, Bisinoto \& Rabelo, 2015). Therefore, the students' participation and attainment, as well as the educational trajectories and competencies to be developed, are mainly related with their expectations when they enter higher education.

Expectations are considered aspirations or targets that justify the students' entry into higher education, strongly guiding their experiences, decision making and engagement in the academic context (Ozdagli \& Trachter, 2014;
Porto \& Soares, 2017). For Byrne et al. (2012), "expectations reflect an individual's anticipation of future events and conditions" (p. 136) and they were associated with motivation for learning, academic success and satisfaction. Hence, the first weeks at university, influenced by the expectations the students bring along, can mean satisfaction and accomplishment for some or disillusion and frustration. In one hand, studies reveal that positive and realistic expectations favor the students' continuing motivation, effort and persistence, as well as the activation of coping strategies, favoring their academic adaptation in the course of the first year of higher education (Nes, Evans, \& Segerstrom, 2009; Neuville, Frenay, \& Bourgeois, 2007). On the other hand, the risk of failure and drop-out in higher education is greater in the group of students who evidence low expectations and weak levels of academic engagement, including those who feel that their initial expectations were dashed in view of their institutional, curricular and interpersonal reality (Krieg, 2013).

The multiple variables in the students' transition, integration and academic success process and their expectations when they enter higher education predict their academic participation and particularly their involvement in the curricular activities (Porto \& Soares, 2017). They also serve as a filter through which the students assess and give meaning to the academic, relational, affective, institutional and professional experiences, considering both their background experiences and future perspectives (Oliveira, Santos, \& Dias, 2016).

The investigation about the academic expectations suggests their distinction according to subgroups of students. The students' sociocultural origin, age and gender are some of the variables considered in this differentiation. For example, the family socioeconomic status was found positively related to educational goals, academic adjustment, academic achievement, and career development (Whiston \& Keller, 2004). Results of studies indicated that students from lower socioeconomic groups present less information about academic and social environments and lower selfefficacy levels in terms of their competencies to overcome the challenges inherent in the transition and adaptation (Cabrera, Burkum, La Nasa, \& Bibo, 2012; Vuong, BrownWelty, \& Tracz, 2010). In addition, research has pointed out that female students tend to present higher levels of involvement and academic achievement (Wells, Seifert, \& Saunders, 2013). While male students are more motivated by the career progression and employment opportunities related to the course, female students have higher expectations for their interpersonal relationships and are more dependent on support from colleagues and family (Demir \& Orthel, 2011), or more responsive to others' opinion and social pressure (Lopez, 2014; Zeldin, Britner, \& Pajares, 2008), which can increase their involvement in curricular activities and academic success (Wells et al., 2013). Kandiko and Mawer (2013) conducted interviews and focus groups with 153 university students, years 1 and 2, across the UK and found that they expected (a) their learning environment to meet benchmarks across instrumental (e.g., computers and 
physical spaces), organizational (e.g., course structure), interpersonal (e.g., staff support) and academic areas (professors' knowledge and attitude towards students); (b) the value of their financial investment to match the value of their educational experience; (c) qualified and trained staff; (d) clear and open processes for evaluation and feedback opportunities; (e) a personalized higher education experience; (f) to interact with other students, participate in social and academic extra-curricular activities; and (g) to improve their career prospects.

In the framework of a research project involving the University of Minho (Portugal), University of VigoOurense (Spain) and University of Brasilia (Brazil), a multidimensional concept was developed of first-year university students' academic expectations (Almeida, Costa, Alves, Gonçalves, \& Araújo, 2012). Seven dimensions were considered: (a) political involvement/citizenship, including concerns with values, ethics and problems or social issues; (b) education for employment/career, i.e. gaining better work conditions or a degree to enter the job world; (c) social interaction with peers or having contact with and making new friends, participating in academic parties and in academic associations or groups; (d) international mobility, i.e. expecting to benefit from learning or professional training experience in another country; (e) social pressure, such as attending to parents, colleagues and teachers' expectations, or pleasing significant others; (f) personal and social development, autonomy, entrepreneurism, self-confidence and critical thinking; and (g) quality of education, with a view to learning, deepening knowledge, knowing more about the area or course of interest.

This international partnership allowed each country to develop the studies needed to consolidate the listed dimensions of the expectations, as well as to choose the items that best guaranteed their assessment. Hence, besides some common dimensions and items, each country advanced in the construction and validation of the final version of the scale that best attended to the purposes of its use. In Brazil, a previous study was conducted, involving 339 university students. The exploratory factor analysis, using principal axis factoring, resulted in 61 items distributed over seven factors: Quality of Academic Development, Social and Academic Commitment, Broadening of Interpersonal Relationships, Opportunity for Students' Exchange and Internationalization, Perspective of Professional Success, Concern with Self-image, and Development of Transversal Competences. The explained variance was $42.75 \%$ and the reliability coefficients (Cronbach's alpha) varied from .71 to 90 (Marinho-Araújo et al., 2015).

Through the present study, we aimed to test the measurement model of the Brazilian Scale of Academic Expectations for First-year University Students, short version. For investigating the measurement model of the scale, we performed a Confirmatory Factor Analysis, inspecting if the theoretical model of seven correlated factors presented good data fit, and we employed an invariance analysis to the scale, verifying if the scale was invariant for some target groups of students. These groups were: (a) students who entered university through the universal selection system and students who entered university through social programs for minorities; (b) male and female students; and (c) partial or full worker and non-worker students. We hope the results of the study might help to construct an invariant scale, capable of performing comparison between groups of students, which will permit to understand the difficulties the students face in the integration and adaptation process to this education level, to support higher education institutions in their review of pedagogical course proposals, and to elaborate programs, services and policies dedicated to first-year students. As this scale concerns academic expectations that could be administered as part of a larger assessment protocol (including several psychosocial and academic variables), it is important to guarantee a brief version to facilitate its use in practice and in research.

\section{Method}

\section{Participants}

The participants in this study were 6,913 students regularly enrolled in the first academic semester of 2015 at a Brazilian federal public university located in the CentralWest of the country. The number of respondents corresponds to $82.1 \%$ of a universe of 8,424 freshmen. Among the participants, $632(n=9.1 \%)$ had already concluded an undergraduate program earlier. The participants' average age was 20.26 years old $(S D=5.66)$, ranging from 16 to 60 . In this group, 3,650 (52.8\%) were male and 3,263 (47.2\%) female; the majority $(n=5,556,80.4 \%)$ informed they did not work, 1,211 (17.5\%) worked, and $146(2.1 \%)$ were trainees. Among the participants, 3,524 (51\%) entered university through the traditional entry exam (Vestibular), 1,731 (25\%) entered through the Serial Assessment Program (PAS) and 1,658 (24\%) entered through the Ministry of Education's Unified Selection Program (SISU).

The PAS Program involves a process-based assessment, applied by the university at the end of each high school year, to test the knowledge that the students acquired during that year. The students are ranked based on the weighted average of the results obtained on the three tests taken, that is, the scores are weighted as 1, 2 and 3, corresponding to the results of the first, second and third years of their secondary education. The SISU is a digital platform developed by the Brazilian Ministry of Education, in which the students who take the High School National Exam (Exame Nacional do Ensino Médio) may use their scores to apply for a place at an undergraduate course at Brazilian public universities. Most of these higher education institutions partially or fully adopt this exam score to replace the traditional entry exam (vestibular). Most students ( $n=4,224$, $61 \%$ ) entered university through the universal selection exam system, while 2,689 (39\%) entered through the quota system, which is a system especially reserved for minorities. This quota system is available for students in two categories: those who have finished public high schools, called social quota, 
and those who consider themselves black or mixed-race, called racial quota.

\section{Instruments}

The Brazilian Scale of Academic Expectations for First-Year University Students short-version. This version consists of 28 items from the full version of the Brazilian Scale of Academic Expectations for First-year University Students (Marinho-Araújo et al., 2015), mentioned before in this paper, which was designed based on the Academic Perceptions Questionnaire - Version A - Expectations (QPA - E) (Almeida et al., 2012).

Each item of the short-scale is answered considering a 6-point scale, ranging from "I completely disagree" to "I completely agree" The scale was created to measure seven academic expectations: (a) Quality of Academic Development, includes 12 items on getting a good preparation to practice the profession (examples: Getting a good academic education according to my interests / Deepening knowledge in my course area); (b) Social and Academic Commitment, includes 13 items, related to the critical-reflexive posture towards social problems, aiming to improve the quality of life in society (examples: Preparing myself as a citizen committed to the problems of the current society / Participating in discussion groups on social problems); (c) Broadening of Interpersonal Relationships, includes eight items that consider the opportunity to establish new relationship networks and participate in extracurricular activities (examples: Having friends who help me get over possible personal difficulties/ Having time each week that allows me to have more contact with fellow students); (d) Opportunity for Student Exchange and Internationalization, includes eight items on the experience and broadening of academic education at foreign institutions (examples: Being able to take some training in another country/ Participating in student exchange by spending some course time in another country); (e) Perspective of Professional Success, includes five items on the possibility of getting a good job, which guarantees stability, through a socially valued profession (examples: Getting education to have a good job/ Having better professional options in the job market); (f) Concern with Self-image, includes six items related to the need to attend to family and friends' expectations as well as the desire to keep a positive perception of oneself (examples: Not disappointing the family or friends by my academic performance/ Studying hard so as not to feel inferior); and (g) Development of Transversal Competences, includes nine items that refer to the development of the ability to mobilize resources to cope effectively with unprecedented professional and personal situations (examples: Gaining competences to be a more responsible and autonomous person/ Learning to cope autonomously with life complexities).

\section{Procedure}

Data collection. The students answered the instrument when they enrolled at the university, after having passed the institution's selection processes. Both the informed consent form and the scale were published online for the participants to access. The voluntary nature of their participation in the study was guaranteed.

Data analysis. All data analyses were run in the statistical software Mplus 7.0 (Muthén \& Muthén, 2014). Weighted least square of means and variance was applied to estimate the parameters in all factor analyses in function of the nonnormal characteristic of the items. Comparative fit index (CFI), Tucker-Lewis index (TLI), and root mean square error of approximation (RMSEA) were applied to investigate the model data fit. Values equal or above .95 for the comparative fit index and the Tucker-Lewis index, as well as values equal to or below .06 for RMSEA indicate good model data fit, while values between .90 and .95 for CFI and TLI, and values between .06 and .10 indicate acceptable data fit (Schumacker \& Lomax, 2004). Data fit from different models were compared through DIFFTEST command, keeping in mind that the null hypothesis test presupposes that both models have equal data fit (Muthén \& Muthén, 2014).

Two fundamental steps composed the data analysis. The first involved the confirmatory factor analysis, aiming to evaluate the proposed factorial structure of the instrument, which assumes measuring seven correlated latent variables that represent different types of academic expectations. This factorial structure claims that each latent variable loads only in four target items and possesses zero loading in the other items of the scale. The second step of data analysis evaluated the invariance properties of the factorial structure through two invariance tests: configural invariance and full invariance. Configural invariance is the simplest form of invariance, only presupposing that both compared groups have the same number of factors. The full invariance evaluates if all parameters of the groups are equal (number of factors, loadings, intercepts, and so on). The models fit of full invariance was compared to the configural models of reference. The configural model served as the baseline of comparison because it is the simplest form of invariance. Only if the full invariance model presented a worse data fit in comparison to the configural model, we would perform other invariance models, inspecting the loading invariance model. We chose to start the invariance analysis with configural invariance and full invariance since the former is the fundamental and initial condition to perform the invariance analysis, and the latter is the stronger form of invariance. If the full invariance presented the same data fit to the configural invariance, so we did not need to perform intermediate invariance models, which are weaker forms of invariance.

Three invariance analyses were performed. The first analysis evaluated if the factorial structure is invariant between students who entered the university through the universal selection system and students who entered through social programs for minorities; the second analysis verified if the structure is invariant between male and female students; and the third analysis investigated if the structure is invariant between part or full-time worker and non-worker students. 


\section{Ethical Considerations}

All procedures used were approved by the Ethics Committee of the University of Brasilia, under the number $485.272 / 2013$.

\section{Results}

The tested model defines seven correlated latent variables that represent different aspects of academic expectations. They are: (1) Quality of Academic Development, (2) Social and Academic Commitment, (3) Broadening of Interpersonal Relationships, (4) Opportunity for Student Exchange and Internationalization, (5) Perspective of Professional Success, (6) Concern with Self-image, and (7) Development of
Transversal Competences. The model fit was acceptable approaching a good data fit $\left(\chi^{2}[329]=9142.49 ; C F I=.954\right.$; $T L I=.947$; RMSEA $=.062$; CI $90 \%=.061$ to .063 ). Table 1 presents the latent variables' loadings in the target items and the factors means and standard deviations. The loadings were high, as the smallest loading equaled .72 , indicating that the target items were good markers of their latent variables.

Table 2 presents the correlations among the seven factors of the model tested. The mean of the correlations was .62 (standard deviation of .12), indicating a considerable relationship among the academic expectations. The most detachable is the correlation of .92 between factor 1 (Quality of Academic Development) and factor 7 (Development of Transversal Competences), which is interesting in the sense that the students' academic expectancy of good education is strongly linked to a diverse personal enrichment approach.

Table 1

Factor Loadings on its Target Items and Cronbach's Alphas, Means and Standard Deviations of the Factors

\begin{tabular}{|c|c|c|c|c|c|c|c|c|c|c|c|c|c|c|}
\hline items & F1 & & F2 & & F3 & & F4 & & F5 & & F6 & & F7 & \\
\hline & load & se & load & se & load & se & load & se & load & se & load & se & load & se \\
\hline $\mathrm{i} 36$ & .86 & .01 & & & & & & & & & & & & \\
\hline i53 & .86 & .01 & & & & & & & & & & & & \\
\hline i57 & .83 & .01 & & & & & & & & & & & & \\
\hline i59 & .86 & .01 & & & & & & & & & & & & \\
\hline i11 & & & .85 & .01 & & & & & & & & & & \\
\hline i14 & & & .81 & .01 & & & & & & & & & & \\
\hline $\mathrm{i} 23$ & & & .82 & .01 & & & & & & & & & & \\
\hline i52 & & & .91 & .01 & & & & & & & & & & \\
\hline i38 & & & & & .72 & .01 & & & & & & & & \\
\hline i06 & & & & & .75 & .01 & & & & & & & & \\
\hline i58 & & & & & .81 & .01 & & & & & & & & \\
\hline $\mathrm{i} 62$ & & & & & .85 & .01 & & & & & & & & \\
\hline i08 & & & & & & & .88 & .01 & & & & & & \\
\hline $\mathrm{i} 20$ & & & & & & & .88 & .00 & & & & & & \\
\hline i55 & & & & & & & .90 & .00 & & & & & & \\
\hline $\mathrm{i} 40$ & & & & & & & .93 & .00 & & & & & & \\
\hline i10 & & & & & & & & & .81 & .01 & & & & \\
\hline i18 & & & & & & & & & .89 & .01 & & & & \\
\hline i24 & & & & & & & & & .94 & .01 & & & & \\
\hline $\mathrm{i} 28$ & & & & & & & & & .86 & .01 & & & & \\
\hline i29 & & & & & & & & & & & .79 & .01 & & \\
\hline i44 & & & & & & & & & & & .79 & .01 & & \\
\hline i16 & & & & & & & & & & & .77 & .01 & & \\
\hline $\mathrm{i} 46$ & & & & & & & & & & & .79 & .01 & & \\
\hline $\mathrm{i} 30$ & & & & & & & & & & & & & .81 & .01 \\
\hline $\mathrm{i} 42$ & & & & & & & & & & & & & .79 & .00 \\
\hline i54 & & & & & & & & & & & & & .87 & .00 \\
\hline i56 & & & & & & & & & & & & & .83 & .00 \\
\hline alphas & .86 & & .88 & & .82 & & .91 & & .89 & & .83 & & .85 & \\
\hline$M$ & 5.62 & & 5.06 & & 4.86 & & 5.07 & & 5.45 & & 4.32 & & 5.39 & \\
\hline$D P$ & .78 & & 1.09 & & 1.16 & & 1.20 & & .92 & & 1.48 & & .91 & \\
\hline
\end{tabular}

Note. $\mathrm{Se}=$ standard error; F1 = Quality of Academic Development; F2 = Social and Academic Commitment; F3 = Broadening of Interpersonal Relationships; F4 = Opportunity for Student Exchange and Internationalization; F5 = Perspective of Professional Success; F6 = Concern with Self-image; F7 = Development of Transversal Competences. 
Table 2

Correlations Among the Seven Factors of the Tested Model

\begin{tabular}{|c|c|c|c|c|c|c|c|}
\hline & F1 & F2 & F3 & F4 & F5 & F6 & F7 \\
\hline $\mathrm{F} 1$ & & .01 & .01 & .01 & .01 & .01 & .01 \\
\hline $\mathrm{F} 2$ & .67 & & .01 & .01 & .01 & .01 & .01 \\
\hline F3 & .64 & .63 & & .01 & .01 & .01 & .01 \\
\hline $\mathrm{F} 4$ & .58 & .45 & .55 & & .01 & .01 & .01 \\
\hline F5 & .84 & .54 & .55 & .54 & & .01 & .01 \\
\hline F6 & .52 & .48 & .68 & .45 & .62 & & .01 \\
\hline F7 & .92 & .76 & .76 & .58 & .72 & .60 & \\
\hline
\end{tabular}

Note. The correlations are presented below the table diagonal and the standard errors are presented above the table diagonal. F1 $=$ Quality of Academic Development; F2 = Social and Academic Commitment; F3 = Broadening of Interpersonal Relationships; F4 = Opportunity for Student Exchange and Internationalization; F5 = Perspective of Professional Success; F6 = Concern with Self-image; F7 = Development of Transversal Competences.

Aiming to observe the invariance of the factorial structure of seven correlated factors, we investigated the configural invariance and the full invariance, comparing the following groups: (a) students who entered the university through the universal selection exam system and students who entered the university through social programs for minorities; (b) male and female students; and (c) part or full-time workers and non-workers. The configural invariance model for the first comparison $(N=4,224$ entered through universal selection exam system; $N=2,689$ entered through minority programs) presented an acceptable data fit $\left(\chi^{2}[658]=9411.88 ; C F I=.955 ; T L I=.948 ; R M S E A=.062\right.$; $C I 90 \%=.061$ to .063 ), indicating that we should infer that the same seven factors are present in both groups. On the other hand, the full invariance presented a better fit than the configural invariance (Chi-Square Test for Difference Testing: $\left.\Delta \chi^{2}[126]=171,43 ; p=.0044\right)$ and showed a good model fit $\left(\chi^{2}[784]=8688.47 ; C F I=.959 ; T L I=.961 ; R M S E A=.054\right.$; $C I 90 \%=.053$ to .055$)$, sustaining evidence that both groups possess the same factors, loadings, intercepts and so on.

The configural invariance model for the second comparison ( $N=3,263$ of females; $N=3,650$ of males) presented an acceptable data fit $\left(\chi^{2}[658]=9367.60\right.$; $C F I=.954 ; T L I=.947 ;$ RMSEA $=.062 ; C I 90 \%=.061$ to .063$)$, indicating that we should infer that the same seven factors are present in both groups. The full invariance presented a better fit than the configural invariance $\left(\Delta \chi^{2}[126]=366,62\right.$; $p<.001)$ and showed a good data fit (Chi-Square Test for Difference Testing: $\Delta \chi^{2}[784]=8970.10 ; C F I=.957$; $T L I=.958 ;$ RMSEA $=.055 ; C I 90 \%=.054$ to .056 ), sustaining evidence that both groups have the same factors, loadings, intercepts and so on. The configural invariance model for the third comparison $(N=1211$ of part or full-time workers; $N=5702$ of non-workers) presented an acceptable data fit $\left(\chi^{2}[658]=9422.26 ; C F I=.950 ; T L I=.943\right.$; RMSEA $=.062 ; C I 90 \%=.061$ to .063$)$, indicating that we should infer that the same seven factors are present in both groups. The full invariance presented a better fit than the configural invariance (Chi-Square Test for Difference Testing: $\left.\Delta \chi^{2}[126]=493.77 ; p<.001\right)$ and showed a good data fit $\left(\chi^{2}[784]=9188.20 ; C F I=.952 ; T L I=.954 ; R M S E A=.056\right.$; $C I 90 \%=.055$ to .057 ), sustaining the same evidence as found in the other groups.

\section{Discussion}

The academic expectations assume an important role on students' adaptation to the university. For first-year students, specially, low academic performance and dropout rates increase when their initial expectations do not match the academic reality that they find in their course and institution (Briggs, Clark, \& Hall, 2012; Nes et al., 2009). The students' permanence and success in academic life depend on the opportunities to gain different skills, to develop interpersonal relationships beyond the classroom, as well as to be part of an institution that welcomes the students and responds to their needs (Yorke \& Thomas, 2003). In this study, we noticed that the three factors with the highest averages were Quality of Academic Development, Perspective of Professional Success, and Development of Transversal Competences, while the factors Concern with Self-image and Broadening of Interpersonal Relationships had the two lowest means. These results suggest that the individual's access to the university does not have as exclusive goal to obtain a good job after graduation, but to develop and to fulfill oneself personally and professionally. This leads us to reflect on the profile of the student both in the first year and after graduation. The investment in higher education seems to go beyond the search for a promising career, but it also involves the construction of an identity as a person and a professional (Marinho-Araújo et al., 2015). Similar results were obtained by Nadelson et al. (2013). The responses regarding academic expectations of first-year students tended to be positive for intrinsic motivators such as career and learning goals. External motivators were found to be less important for the students, with the exception of making more money. Furthermore, in a study conducted by Porto and Soares (2017), academic involvement predicted $21 \%$ of adaptation to university. These findings support the relevance of designing pedagogical strategies that could meet students' academic needs and interests.

Long-term expectations, such as previous beliefs about the course or profession and family desire regarding the student's professional aspiration (e.g., personal and professional fulfillment and family acceptance), as well as short-term expectations related to beliefs about how he/she will be welcomed (e.g., institution facilities, infrastructure, 
quality of the faculty staff, and relationship building) were found by Moreno and Soares (2014) in a qualitative study with 13 university students. The results obtained in the present study also highlight the importance given by the participants to the academic development and professional success, but, on the other hand, they do not deal with other factors that, in the Moreno and Soares' investigation, seem to influence on academic expectations as, for example, family background, pointing out the need for further investigation.

As stated by Casanova and Almeida (2016), most students are satisfied with their entrance to higher education because they expect to deepen the knowledge and to develop personal, social, professional competences during their stay at the university. However, although admission to university is much desired, several difficulties may arise with the transition between high school and higher education, especially those related to psychosocial issues and poor academic achievement. In addition, the discrepancy between initial expectations and later academic experiences can lead to disenchantment, mismatch, and confusion in relation to academic life. Casanova and Almeida further state that not being accepted at the desired institution, nor being admitted to their first-choice course may contribute to the lack of investment in academic life. In this regard, the association between these factors, expectations, and adaptation to the university context could be addressed in future studies.

Considering the diverse profiles of Brazilian higher education students in recent years, expectations may differ and, consequently, their experiences, thus impacting positively or negatively on their permanence in the institution and on the conclusion of the course. For Porto and Soares (2017), it is important to assess the expectations of first-year students so that the institutions understand their needs, make available or improve services and programs that allow them to adapt to this level of education. Findings obtained by Soares, Monteiro, Porto, Gomes, and Gomes (2016) with first-year students of psychology, through open questionnaires, revealed that the participants believed to be the institution's responsibility to solve problems faced in the process of students' adaptation to the university. For them, the institution, colleagues and teachers should support and meet their personal needs. Understanding the expectations of the students, according to the authors of the research, is a way to subsidize institutions of higher education with information in order to help them to create a welcoming and motivating climate capable of minimizing the impasses and difficulties that may emerge in the transition period from high school to higher education.

From the methodological perspective, the 28 -item scale was appropriate to measure the seven dimensions of academic expectations. Some evidence supporting this argument are: (1) the model with seven correlated factors presented good fit to the data, (2) the factor loadings were high, ranging between .72 and .94 , and (3) the model with seven correlated factors demonstrated full invariance in the three categories: gender, university access modality, and work. The academic expectations play a relevant role in the student's academic trajectory and permanence at the university. In addition, it can be hypothesized that distinct academic expectations are present in different student groups, considering that the expansion of higher education, accompanied by more democratic access, led not only to a considerable increase in the number of students in most countries, but also to the progressive differentiation of the student population. While the comparison among different groups is extremely relevant, it is necessary to keep in mind that this comparison is feasible when there is evidence that the instrument used is invariant in its internal structure for the groups compared. Different techniques exist to obtain evidence on the invariance of a measure. The Rasch model family can be mentioned, which constructs a true measure and verifies the degree of fit of the scale items to this measure, as well as the invariance analysis through factorial analysis. In this study, the invariance analysis of the 28-item scale permits checking whether this tool can collect data and compare different groups in the university population. The evidences about the full invariance of this scale concerning the criteria under investigation sustain its use to compare the level of expectations among the groups with regard to the criteria analyzed. Although many studies from different fields of psychology and education compare different groups without evidence of invariance of the data collection tool, the psychometric literature argues that this practice lacks technical foundations. To be able to compare groups in terms of factorial structure, the instrument at least needs the same factorial structure (same factors) and the same factor loadings need to be present in the different groups for comparison (Milfont \& Fischer, 2010). In that sense, this study advances by providing a scientifically sound scale with technical analyses to sustain its use for effective comparisons among groups of university students. The validity evidence obtained for the scale analyzed in this study points towards its relevance in mapping first-year university students' expectations. Furthermore, in addition to the gain that always results from the application of short version scales in research protocols with more variables to study, the selection of items that remain reinforces the specificity of each dimension, and this allows us in the future to advance with greater security in the identification of differentiated profiles of students, thus guiding research and intervention.

The scale can contribute to support higher education institutions in their educational policies and actions. The validity evidence obtained for the scale analyzed in this study points towards its relevance in mapping freshmen students' expectations. The scale can also contribute to support higher education institutions in their educational policies and actions. To identify the first-year university students' profile, different studies can be developed with the help of this instrument, evaluating the academic expectations of students when they enter higher education. In particular, in view of the change in Brazilian university students' profile in the past decade, resulting from the social insertion and affirmative action policies, based on the evidence from our study, we argue that the 28 -item scale can support data collection for future research to (a) analyze differences in expectations in view of gender and university entrance modality; (b) compare working and non-working students; (c) correlate students' expectations and performance along their academic trajectory; (d) compare the expectations in 
their freshman year and some years after starting the course; (e) correlate students' expectations with psychological well-being upon entering university; (f) analyze the effects of a secondary school-higher education transition program for first-year students. As a study limitation, it is emphasized that, despite the large number of participating students, all of them attended a single public higher education institution. The sample needs to be expanded to represent other university contexts, such as state universities, private colleges, and technical institutes. Also, as any self-report data, we were limited to the data provided by the participants. The use of this scale in combination with other instruments (e.g., interviews) may be a fruitful line for future studies.

\section{References}

Almeida, L. S., Costa, A. R., Alves, A. F., Gonçalves, P., \& Araújo, A. M. (2012). Expetativas académicas dos alunos do ensino superior: Construção e validação de uma escala de avaliação [Academic expectations of university students: Design and validation of an evaluation scale]. Psicologia, Educação e Cultura, 16(1), 70-85. Retrieved from http://recipp.ipp.pt/handle/10400.22/2356

Briggs, A. R. J., Clark, J., \& Hall, I. (2012). Building bridges: Understanding student transition to university. Quality in Higher Education, 18(1), 3-21. doi:10.1080/1 3538322.2011 .614468

Britto, L. P. L., Silva, E. O., Castilho, K. C., \& Abreu, T. M. (2008). Conhecimento e formação nas IES periféricas: Perfil do aluno "novo" da educação superior [Knowledge and academic training in the peripheral higher education institutions: Profile of the "new" undergraduate student]. Avaliação (Campinas), 13(3), 777-791. doi:10.1590/ S1414-40772008000300008

Byrne, M., Flood, B., Hassall, T., Joyce, J., Arquero Montaño, J. L., González, J. M. G., \& Tourna-Germanou, E. (2012). Motivations, expectations and preparedness for higher education: A study of accounting students in Ireland, the UK, Spain and Greece. Accounting Forum, 36(2), 134144. doi:10.1016/j.accfor.2011.12.001

Cabrera, A. F., Burkum, K. R., La Nasa, S. M., \& Bibo, E. (2012). Pathways to a four-year degree: Determinants of degree completion among socioeconomically disadvantaged students. In A. Seidman (Ed.), College student retention: Formula for student success (pp. 155-209). Lanham, MD: Rowman \& Littlefield.

Casanova, J. R., \& Almeida, L. S. (2016). Diversidade de públicos no ensino superior: Antecipando riscos na qualidade da adaptação e do sucesso académico em estudantes do $1^{\circ}$ ano [Public diversity in higher education: Anticipating risks in the quality of adaptation and academic success for students of 1st year]. Psicologia, Educação e Cultura, 20(1), 27-45.
Demir, M., \& Orthel, H. (2011). Friendship, real-ideal discrepancies, and well-being: Gender differences in college students. The Journal of Psychology, 145(3), 173-193. doi:10.1080/00223980.2010.548413

Instituto Nacional de Estudos e Pesquisas Educacionais Anísio Teixeira. (2017). Sinopses estatísticas da educação superior - graduação [Statistical notes of higher education]. Retrieved from http://portal.inep. gov.br/web/guest/sinopses-estatisticas-da-educacaosuperior

Kandiko, C. B., \& Mawer, M. (2013). Students expectations and perceptions of higher education: A study of UK higher education: Project report. London, United Kingdom: King's Learning Institute. Retrieved from https://www.kcl.ac.uk/study/learningteaching/kli/ People/Research/DL/QAAReport.pdf

Krieg, D. B. (2013). Higher expectations for higher education? Perceptions of college and experiences of stress prior to and through the college career. College Student Journal, 47(4), 635-643.

Lopez, J. D. (2014). Gender differences in selfefficacy among latino college freshmen. Hispanic Journal of Behavioral Sciences, 36(1), 95-104. doi:10.1177/0739986313510690

Marinho-Araújo, C. M., Almeida, L. S., Fleith, D. S., Bisinoto, C., \& Rabelo, M. L. (2015). Adaptação da Escala Expectativas Acadêmicas de Estudantes Ingressantes na Educação Superior [Adaptation of the Academic Expectation Scale of Freshman University Students]. Avaliação Psicológica, 14(1), 133-141. doi:10.15689/ap.2015.1401.15

Milfont, T. L., \& Fischer, R. (2010). Testing measurement invariance across groups: Applications in cross-cultural research. International Journal of Psychological Research, 3(1), 111-121. doi:10.21500/20112084.857

Muthén, L. K., \& Muthén, B. O. (2014). Mplus users's guide. Los Angeles, CA: Muthén \& Muthén.

Moreno, P. F., \& Soares, A. B. (2014). O que vai acontecer quando eu estiver na universidade? Expectativas de jovens estudantes brasileiros [What will happen when I will be in college? Expectations of young Brazilian students]. Aletheia, (45), 114-127. Retrieved from http://pepsic.bvsalud.org/scielo.php?script $=$ sci arttext\&pid=S1413-03942014000200009

Nadelson, L. S., Semmelroth, C., Martinez, G., Featherstone, M., Fuhriman, C. A., \& Sell, A. (2013). Why did they come here? The influence and expectations of first-year students' college experience. Higher Education Studies, 3(1), 50-62. doi:10.5539/hes.v3n1p50 
Nes, L. S., Evans, D. R., \& Segerstrom, S. C. (2009). Optimism and college retention: Mediation by motivation, performance, and adjustment. Journal of Applied Social Psychology, 39(8), 1887-1912. doi:10.1111/j.15591816.2009.00508.x

Neuville, S., Frenay, M., \& Bourgeois, E. (2007). Task value, self-efficacy and goal orientations: Impact on self-regulated learning, choice and performance among university students. Psychologica Belgica, 47(1-2), 95-117. doi:10.5334/pb-47-1-95

Oliveira, C. T., Santos, A. S., \& Dias, A. C. G. (2016). Expectativas de universitários sobre a universidade: Sugestões para facilitar a adaptação acadêmica [University students' expectations about the university: Suggestions for facilitating the academicadaptation]. Revista Brasileira de Orientação Profissional, 17(1), 43-53. Retrieved from http://pepsic.bvsalud.org/scielo.php?script=sci_ arttext\&pid=S1679-33902016000100006

Organization for Economic Co-operation and Development. (2014). Education at a glance 2014: Highlights. Retrieved from http://www.oecd-ilibrary.org/education/ education-at-a-glance-2014_eag_highlights-2014-en

Organization for Economic Co-operation and Development. (2017). Education at a glance 2017: OECD indicators. Retrieved from https://www.oecd-ilibrary.org/education/ education-at-a-glance-2017_eag-2017-en

Ozdagli, A., \& Trachter, N. (2014). The dropout option in a simple model of college education. Economic Quarterly, 100(4), 279-295. Retrieved from https:// www.richmondfed.org/publications/research/economic_ quarterly/2014/q4/trachter

Porto, A. M. S., \& Soares, A. B. (2017). Expectativas e adaptação acadêmica em estudantes universitários [Expectations and college adjustment in college students]. Psicologia: Teoria e Prática, 19(1), 208-219. doi:10.5935/1980-6906/psicologia.v19n1p208-219

Rabelo, M. L., Bisinoto, C., Marinho-Araujo, C., Griboski, C., \& Meneghel, S. M. (2015). Educação superior brasileira: Perfil dos concluintes e sua percepção sobre a formação [Brazilian higher education: Profile of senior students and their perception on academic training]. Revista de Estudios y Investigación en Psicología y Educación, (14), 72-76. doi:10.17979/reipe.2015.0.14.869
Ristoff, D. (2014). O novo perfil do campus brasileiro: Uma análise do perfil socioeconômico do estudante de graduação [The new profile of the Brazilian campus: An analysis of the socioeconomic profile of undergraduate students]. Avaliação (Campinas), 19(3), 723-747. doi:10.1590/S1414-40772014000300010

Schumacker, R. E., \& Lomax, R. G. (2004). A beginner's guide to structural equation modeling. London, United Kingdom: Lawrence Erlbaum.

Soares, A. B., Monteiro, M. C., Porto, A. M. S., Gomes, G., \& Gomes, C. A. O. (2016). Expectativas acadêmicas de estudantes de psicologia brasileiros: Estudo comparativo entre iniciantes e concluintes [Academic expectations of Brazilian students of psychology: A comparative study between beginners and graduates]. Psicologia, Educação e Cultura, 20(1), 46-64.

United Nations Educational, Scientific and Cultural Organization. (2017). Education: Enrolment by education level. Retrieved from http://data.uis.unesco.org/Index. aspx?queryid $=128$

Vuong, M., Brown-Welty, S., \& Tracz, S. (2010). The effects of self-efficacy on academic success of first-generation college sophomore students. Journal of College Student Development, 51(1), 50-64. doi:10.1353/csd.0.0109

Wells, R. S., Seifert, T. A., \& Saunders, D. B. (2013). Gender and realized educational expectations: The roles of social origins and significant others. Research in Higher Education, 54(6), 599-626. doi:10.1007/s11162-0139308-5

Whiston, S. C., \& Keller, B. K. (2004). The influences of the family of origin on career development: A review and analysis. The Counseling Psychologist, 32(4), 493-568. doi: $10.1177 / 0011000004265660$

Yorke, M., \& Thomas, L. (2003). Improving the retention of students from lower socio-economic groups. Journal of Higher Education Policy and Management, 25(1), 63-74. doi:10.1080/13600800305737

Zeldin, A. L., Britner, S. L., \& Pajares, F. (2008). A comparative study of the self-efficacy beliefs of successful men and women in mathematics, science, and technology careers. Journal of Research in Science Teaching, 45(9), 1036-1058. doi:10.1002/tea.20195 
Denise de Souza Fleith is a Professor of the Institute of Psychology at Universidade de Brasília, Brasília-DF, Brazil.

Leandro Silva Almeida is a Professor of the Institute of Education at Universidade do Minho, Braga, Portugal.

Claisy Maria Marinho-Araujo is a Professor of the Institute of Psychology at Universidade de Brasília, Brasília-DF, Brazil.

Cristiano Mauro Assis Gomes is a Professor of the Departament of Psychology at Universidade Federal de Minas Gerais, Belo Horizonte-MG, Brazil.

Cynthia Bisinoto is a Professor of the Faculdade UnB Planaltina at Universidade de Brasília, Brasília-DF, Brazil.

Mauro Luiz Rabelo is a Professor of the Departament of Mathematics at Universidade de Brasília, Brasília-DF, Brazil.

\section{Authors' Contribution:}

All authors made substantial contributions to the conception and design of this study, to data analysis and interpretation, and to the manuscript revision and approval of the final version. All authors assume public responsibility for the content of the manuscript.

Received: Feb. 01, 2018

1st Revision: May. 28, 2018

2nd Revision: Jun. 12, 2018

Approved: Jun. 30, 2018

How to cite this article:

Fleith, D. S., Almeida, L. S., Marinho-Araujo, C. M., Gomes, C. M. A., Bisinoto, C., \& Rabelo, M. L. (2020). Validity evidence of a scale on academic expectations for higher education. Paidéia (Ribeirão Preto), 30, e3010. doi:http://dx.doi.org/10.1590/1982-4327e3010 


\section{Appendices}

Brazilian Scale of Academic Expectations for First-year University Students - short version

\begin{tabular}{|c|c|c|c|c|c|c|}
\hline While attending higher education, I hope to ... & 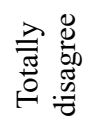 & 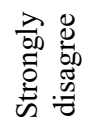 & 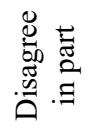 & 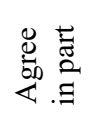 & 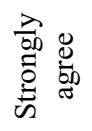 & 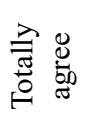 \\
\hline $\begin{array}{l}\text { 1. Have friends who help me overcome possible personal } \\
\text { difficulties. }\end{array}$ & 1 & 2 & 3 & 4 & 5 & 6 \\
\hline $\begin{array}{l}\text { 2. Participate in university student exchange programs } \\
\text { (Science without frontiers, for example). }\end{array}$ & 1 & 2 & 3 & 4 & 5 & 6 \\
\hline 3. Have better professional options in the job market. & 1 & 2 & 3 & 4 & 5 & 6 \\
\hline $\begin{array}{l}\text { 4. Understand how I can contribute to improving the world } \\
\text { and society. }\end{array}$ & 1 & 2 & 3 & 4 & 5 & 6 \\
\hline $\begin{array}{l}\text { 5. Engage in solving problems of socially disadvantaged } \\
\text { people. }\end{array}$ & 1 & 2 & 3 & 4 & 5 & 6 \\
\hline $\begin{array}{l}\text { 6. Participate in study activities so as not to be excluded by } \\
\text { colleagues. }\end{array}$ & 1 & 2 & 3 & 4 & 5 & 6 \\
\hline 7. Get training to have a good job in the future. & 1 & 2 & 3 & 4 & 5 & 6 \\
\hline 8. Get to do some internship in another country. & 1 & 2 & 3 & 4 & 5 & 6 \\
\hline 9. Participate in volunteering activities in the community. & 1 & 2 & 3 & 4 & 5 & 6 \\
\hline 10. Be trained to succeed professionally in the future. & 1 & 2 & 3 & 4 & 5 & 6 \\
\hline 11. Increase the possibility of a stable job in the future. & 1 & 2 & 3 & 4 & 5 & 6 \\
\hline 12. Work hard, so as not to feel inferior to my colleagues. & 1 & 2 & 3 & 4 & 5 & 6 \\
\hline 13. Increase my capacity for reflection and argumentation. & 1 & 2 & 3 & 4 & 5 & 6 \\
\hline $\begin{array}{l}\text { 14. Have the necessary preparation to carry on the profession } \\
\text { I desire. }\end{array}$ & 1 & 2 & 3 & 4 & 5 & 6 \\
\hline 15. Expand my social network of friends. & 1 & 2 & 3 & 4 & 5 & 6 \\
\hline $\begin{array}{l}\text { 16. Participate in student exchanges spending some time of } \\
\text { the program in another country. }\end{array}$ & 1 & 2 & 3 & 4 & 5 & 6 \\
\hline 17. Learn to deal autonomously with the complexities of life. & 1 & 2 & 3 & 4 & 5 & 6 \\
\hline 18. Not to stay behind colleagues with respect to grades. & 1 & 2 & 3 & 4 & 5 & 6 \\
\hline $\begin{array}{l}\text { 19. Not to disappoint family or friends concerning my } \\
\text { academic achievement. }\end{array}$ & 1 & 2 & 3 & 4 & 5 & 6 \\
\hline $\begin{array}{l}\text { 20. Contribute to the improvement of the human condition or } \\
\text { the well-being of people. }\end{array}$ & 1 & 2 & 3 & 4 & 5 & 6 \\
\hline 21. Deepen my knowledge in the area of my major/course. & 1 & 2 & 3 & 4 & 5 & 6 \\
\hline $\begin{array}{l}\text { 22. Acquire competencies to be a more responsible and } \\
\text { autonomous person. }\end{array}$ & 1 & 2 & 3 & 4 & 5 & 6 \\
\hline 23. Take internships abroad to gain international recognition. & 1 & 2 & 3 & 4 & 5 & 6 \\
\hline $\begin{array}{l}\text { 24. Develop communication skills (oral, written, nonverbal } \\
\text { etc). }\end{array}$ & 1 & 2 & 3 & 4 & 5 & 6 \\
\hline $\begin{array}{l}\text { 25. Obtain a good academic background in accordance with } \\
\text { my interests. }\end{array}$ & 1 & 2 & 3 & 4 & 5 & 6 \\
\hline 26. Have moments of social interaction and enjoyment. & 1 & 2 & 3 & 4 & 5 & 6 \\
\hline $\begin{array}{l}\text { 27. Take the opportunity I have to get a degree in higher } \\
\text { education. }\end{array}$ & 1 & 2 & 3 & 4 & 5 & 6 \\
\hline 28. Meet and interact with different people. & 1 & 2 & 3 & 4 & 5 & 6 \\
\hline
\end{tabular}

